\title{
Seroprevalence and Risk Factors for Toxoplasma gondii Infection in Goats in Southern Brazil
}

\author{
Anderson Barbosa de Moura', André Ribeiro' , Antonio Pereira de Souza', Marcio Orides da Silva', \\ Gustavo Machado², Vanderlei Klauck ${ }^{3}$, Rafael Pazinato ${ }^{3}$ \& Aleksandro Schafer Da Silva ${ }^{3}$
}

\begin{abstract}
Background: Toxoplasma gondii is a coccidium, obligate intracellular protozoan, with complex life cycle, affecting virtually all-animal species homoeothermics. Goats are considered susceptible to infection by $T$. gondii, alterations being reported as pathological fetal death (with subsequent reabsorption), abortion, mummification, and/or the birth of weak goats. Because of these consequences to the animal, the disease is investigated throughout the Brazilian territory. Therefore, the aim of this study was to estimate the seroprevalence of Toxoplasma gondii antibodies and identify risk factors in goats.

Materials, Methods \& Results: It were collected 654 blood samples from goats distributed on west and mountainous regions of Santa Catarina, Brazil. The number municipalities with the highest numbers of goats were used, with an expected prevalence of $25 \%$, error of $3.2 \%$ and confidence level of $95 \%$. All collected samples were tested by indirect immunofluorescence assay (IFA), and 216 (33.02\%; 95\% CI 29.43-36.77) had antibodies against $T$. gondii (IFA $\geq 1$ : 64). Titration $1: 64$ was observed more frequently $(60.2 \% ; 130 / 216)$ among seropositive animals. The region with the highest prevalence was the west, i.e., more prone to infections present, with 1.16 more chances than the mountainous region. Animals Boer were more likely to T. gondii infection, being race is a risk factor for disease. When the presence of cats on the property, and these animals had chances of direct contact with cats, the chance of infection increased significantly, being 1.04 times higher went compared with lack of this feature. Regarding age, the animals aged two to five years had higher seropositivity $(77.8 \%)$. Statistical analysis of effect-cause studies reported a relationship between soropositive animals and neurological problems $(P \leq 0.05)$, but no relation was found for $T$. gondii infection and reproductive problems $(P>0.05)$.

Discussion: In the state of Santa Catarina, approximately $33 \%$ of the goats were seropositive for $T$. gondii, according to results of this study. Several other studies has been performed on T. gondii antibodies detection in Brazil, such as Paraná which was $44.68 \%$, in Rio Grande do Norte was $17.1 \%$, in Rio de Janeiro was $29.12 \%$, in Maranhão was 36.95\%, in Bahia was $17.4 \%$, in Minas Gerais was 21.4\%, in Alagoas was 39\% and in Rio Grande do Sul was 30\%. The type of food and water source given to the animals was not considered a risk factor for $T$. gondii infection, although some authors mention that cat feces contaminated with oocysts of the parasite can be more easily ingested in the diet with concentrated (cats have access) and natural water sources. This study showed that $53 \%$ of the animals studied had contact with cats, and this variable was considered a risk factor for disease. Statistically, unverified relationship between reproductive problems and goats seropositive for $T$. gondii, although of approximately $24 \%$ of the animals studied showed some reproductive problems (abortion, mummified or heat repetition). In the effect-cause analysis, neurological issues were related to infection by $T$. gondii in goats, the that can easily be explained because the parasitic cysts of $T$. gondii may persist in the central nervous system for a long period. The results suggest that infection by $T$. gondii occurs in goats in two regions of Santa Catarina, in addition, and the risk factors related to disease was between both studied regions, race and presence and contact with cats, just as there is a relation between disease and neurological disorders in goats.
\end{abstract}

Keywords: goat, Toxoplasma gondii, neurological disorders.

'Departamento de Medicina Veterinária (DMV), Centro de Ciências Agroveterinárias (CAV), Universidade do Estado de Santa Catarina (UDESC), Lages, SC, Brazil. ${ }^{2}$ Laboratório de Epidemiologia Veterinária, Faculdade de Veterinária, Universidade Federal do Rio Grande do Sul (UFRGS), Porto Alegre, RS, Brazil. ${ }^{3}$ Departamento de Zootecnia (DZO), Centro de Educação Superior do Oeste (CEO), UDESC, Chapecó, SC. CORRESPONDENCE: A.S. Da Silva [aleksandro_ss@yahoo.com.br - Tel +55 (49) 2049-9560]. Departamento de Zootecnia, Universidade do Estado de Santa Catarina (UDESC). Rua Beloni Trombeta Zanini n. 680E. Bairro Santo Antônio. CEP 89815-630 Chapecó, SC, Brazil. 


\section{INTRODUCTION}

Toxoplasma gondii is a coccidium, obligate intracellular protozoan, with complex life cycle, affecting virtually all-animal species homoeothermics [10]. The life cycle of $T$. gondii is presented in three ways, that is, tachyzoites, bradyzoites and oocysts [14] as well as the felines are the definitive hosts $[10,14]$. According to the literature, the domestic animals (intermediate hosts) most commonly involved with toxoplasmosis are pigs, sheep and goats, followed by less frequently dogs, rabbits, horses, birds and, finally, to a lesser extent are cattle and buffalo [33].

The first description of goat's toxoplasmosis as important reproductive problems occurred in Australia [27]. According to literature, goats are considered susceptible to infection by $T$. gondii [9], alterations being reported as pathological fetal death (with subsequent reabsorption), abortion, mummification, and/or the birth of weak goats [12]. Furthermore, death may occur rarely in adult goats, disseminated acute toxoplasmosis has being described with most recurrent clinical signs of encephalitis, fever, diarrhea, dyspnea, lethargy, pulmonary congestion and edema, renal infarction, necrotic foci in the liver and spleen, enteritis, cystitis and abomasite [8,25].

Although some soroepidemiological studies of goat toxoplasmosis have been done in many states of Brazil, in Santa Catarina state this information still lacking. In consequence, the objective of this study was to evaluate the seroprevalence of $T$. gondii in goats, and identify risk factors related to the occurrence of the disease in Santa Catarina regions.

\section{MATERIALS AND METHODS}

Blood samples were obtained from 654 goats in 57 municipalities in the western and mountain regions of the state of Santa Catarina (SC), Brazil (Figure 1), between August 2012 and March 2013. The animals were randomly chosen in order to represent different stages of development and weight, as well as different productive purposes (meat and milk). The sample distribution was in accordance with the distribution of goat's flocks across SC. This study the number municipalities with the highest numbers of goats were used, with an expected prevalence of $25 \%$, error of $3.2 \%$ and confidence level of $95 \%$.

The animals were manually restrained and blood samples were collected by venipuncture (Vacu- tainer $^{\circledR}$ ) from the external jugular vein. Blood samples were placed in tubes without anticoagulant and kept under refrigeration $\left(10^{\circ} \mathrm{C}\right)$. They were then centrifuged and the serum was frozen $\left(-20^{\circ} \mathrm{C}\right)$ until analysis by Immunofluorescence Assay (IFA).

The identification of immunoglobulin $\mathrm{G}$ ( $\mathrm{IgG}$ ) anti-T. gondii in blood serum was performed by IFA using microscope slides containing tachyzoites of $T$. gondii $\mathrm{RH}$ strain. Sera samples were previously diluted in PBS (pH 7.2) up to 1:64 were used. Samples were incubated for $40 \mathrm{~min}$ at $37^{\circ} \mathrm{C}$ in a humidified chamber. A secondary antibody, an anti-goat-IgG conjugated to fluorescein ${ }^{1}$, was added and incubated for $40 \mathrm{~min}$ at $37^{\circ} \mathrm{C}$ in a humidified chambre [4]. Sera samples from positive and negative sheep were used as controls. All sera samples positives at dilutions of 1:64 were subjected to maximum titration [29]. IFA reactions, with peripheral or diffuse fluorescence of tachyzoites were considered positive, as well as fluorescence with apical or polar reactions were considered negative.

To study risk factors and cause-effect relation of toxoplasmosis in goats an interview with farmer was performed. The following questions were asked regarding each animal: region (west or mountain), breed (non-breed, Boer or Anglo), sex (male or female), age (between 6 months and 1 year, or more than 1 year), diet (with concentrate or without concentrate), water source (natural, river, well water or piped water), reproductive issues (yes or no), neurological issues (yes or no), type of production (milk, meat or mixed) and contact with cats (yes or no).

All variables collected by the questionnaire were tested for its frequency distribution; continuous variables were tested by histogram, mean, standard deviation and range. For categorical variables were performed frequency distribution and bar charts. The whole statistical process was carried out with $\mathrm{R}$ language, v.3.1.1 (R Development Core Team 2009). Variables with large amounts of missing data $(>10 \%)$ and limited variability $(<20 \%)$ were not included in the univariable analysis. A univariate analysis was performed with the Pearson chi-squared test $(\chi 2)$, while a chi-square test for linear trends or Fisher's exact test was initially used to examine the association between positivity in BTM samples and the remaining eight independent variables. A crude prevalence ratio (PR) was applied to assess the impact of individual factors on outcomes [24]. A multivariable Poisson regression with robust variance was used to estimate the adjusted 
prevalence ratio (PR) and 95\% confidence interval (95\% CI) of the estimates [7]. Poisson approach was chosen as recommended by Barros and Hirakata [3]. Univariate analysis was first conducted using all the eight pre-selected variables. Subsequently, all variables with $P \leq 0.20$ were selected for inclusion in the multivariable analysis. Variance inflation factor (VIF) were estimated to verify relationship between all selected independent variables to check for potential collinearity, in which coefficient $>2.50$ was considered as high, if any high VIF is found variable with lowers p-value was considered for the multivariable model.

A second univariate model was built in order to test for a effect-cause presence, it was used here as outcome variable the presence either reproductive issue or neural issue and as predicted variable the diagnostic test result for $T$. gondii infection, for this model a $P \leq$ 0.05 was considered significant associated.

Multivariate models were built in a manual forward method; each remaining variable was added to the best previous model, selected by the Akaike Information Criterion (AIC). A backwards elimination step was used, resulting in a final model in which only variables with $P \leq 0.05$ were retained. Confounding effects were investigated by checking changes in the point estimates of the variables that remained in the model. Changes in parameter estimates $>25 \%$ were considered as a confounder and kept in the model until the final model, and finally two-way interaction terms between variables with biological plausibility were investigated. We used deviance perform as a goodness of fit test for overall model.

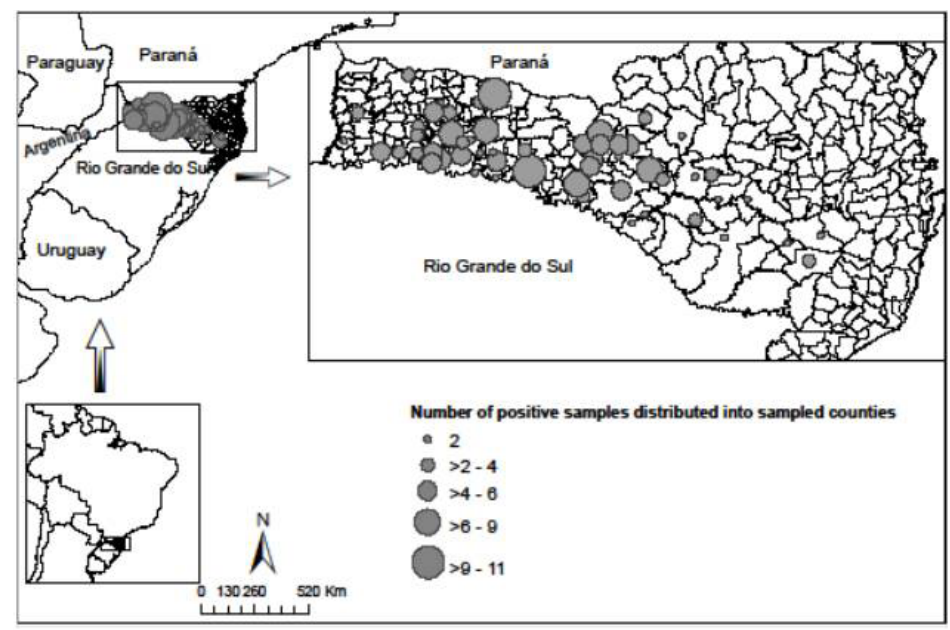

Figure 1. Map of the studied area showing farm location in Santa Catarina State, state borders, and neighboor countries. Sampled farms are indicated by grey circles and the size of each circle represents the amount of positive samples.

\section{RESULTS}

Among the 654 samples analyzed, 216(33.02\%; IC95\% 29.43-36.77) of the samples were seropositive for $T$. gondii distributed in both regions studied. In west region it was found the highest concentration of seropositive samples, i.e. $82.9 \%$ (Table 1). Among the 216 seropositive samples, $60.2 \%(n=130)$ had titration $1: 64,30.5 \%(n=66)$ had title $1: 256,6.1 \%(n=13)$ had titration $1: 1024$ and $3.2 \%(n=7)$ had a titer of 1:4096.

In the univariate analysis, the region, sex, age, water source, breed, and contact with cats were significantly associated with $T$. gondii infection $(P<0.20)$ [Table 1]. Nevertheless, for the multivariate model analyses on the region, breed and contact with cats were considered to be risk factor (Table 2). The region were the samples came from was considered risk factor, been the west region more likely to have the infectious 1.16 in comparison to the mountain; breed was also significant associated with $T$. gondii infection, and one can notice that when animal breed was Boer in comparison to mixed breed the chances of seropositive was 1.64 greater; and finally the presence of contact with cats on the flock represented more chances of T. gondii infection been identified 1.04. None of the two-way interaction terms were significant at $5 \%$ and none potential confounding variables were identified. The model goodness-of-fit was tested by deviance chi-squared test found to be not significant $(P>0.05)$.

It was found significant relation between the presence of neural issue and being tested se- 
ropositive for $T$. gondii infection, tested positive the other hand it was found no significant relation represented a PR of $1.02(1.00-1.03) P<0.001$ for the presence of neural problems been reported. On between reproduction issue and $T$. gondii infection $(P=0.92)$.

Table 1. Univariate analysis of risk factors for toxoplasmosis infection in goats from Santa Catarina (West side), southern Brazil. Period of August 2012 and March 2013.

\begin{tabular}{|c|c|c|c|c|}
\hline Variable & No. of animals & Frequency (\%) & $P$ - value & $\mathrm{PR}^{*}(\mathrm{IC} 95 \%)$ \\
\hline Region & 654 & & & \\
\hline Mountain & & 25 & $<0.001$ & - \\
\hline West & & 75 & & $0.91(0.87-0.96)$ \\
\hline Sex & 654 & & & \\
\hline Male & & 20 & 0.04 & - \\
\hline Female & & 80 & & $0.94(0.90-0.99)$ \\
\hline \multicolumn{5}{|l|}{ Age } \\
\hline 6 months -1year & 654 & 7 & 001 & - \\
\hline 1 year - 2 years & & 15 & 0.01 & $0.89(0.81-0.97)$ \\
\hline$>2$ years & & 78 & & $0.92(0.85-0.98)$ \\
\hline Diet & 654 & & 0.44 & \\
\hline \multirow{2}{*}{\multicolumn{5}{|c|}{$\begin{array}{c}\text { With concentrate } \\
\text { Without } \\
\text { concentrate }\end{array}$}} \\
\hline & & & & \\
\hline Water source & 654 & & 0.17 & \\
\hline Natural source & & 53 & & - \\
\hline River & & 9 & & $0.94(0.86-1.02)$ \\
\hline Wellwater & & 30 & & $0.97(0.92-1.02)$ \\
\hline Piped water & & 8 & & $0.97(0.90-1.05)$ \\
\hline Breed & 654 & & $<0.001$ & \\
\hline Mixed breed & & 70 & & $10{ }^{-}$ \\
\hline Boer & & 27 & & $1.10(1.06-1.15)$ \\
\hline Anglo & & 3 & & $1.08(0.95-1.22)$ \\
\hline Production type & 654 & & 0.45 & \\
\hline Milk & & 3 & & - \\
\hline Meat & & 87 & & $0.99(0.85-1.15)$ \\
\hline Mixed & & 10 & & $0.93(0.79-1.10)$ \\
\hline Contact with cats & 654 & & 0.19 & \\
\hline Yes & & 53 & & $1.03(0.94-1.02)$ \\
\hline No & & 47 & & - \\
\hline
\end{tabular}

*PR: prevalence ratio.

Table 2. Multivariate analysis of risk factors for toxoplasmosis infection in goats from Santa Catarina state (West side), southern Brazil. Period of August 2012 and March 2013.

\begin{tabular}{cccc}
\hline Variable & Estimate $(\beta)$ & $P$ - value & PR* $(\mathrm{CI}: 95 \%)$ \\
\hline Region & - & $<0.001$ & - \\
Mountain & - & & $1.16(1.10-1.22)$ \\
West & 0.14 & - & - \\
Breed & - & $<0.011$ & $1.64(1.11-1.22)$ \\
Mixed breed & 0.11 & $1.11(0.97-1.27)$ \\
Boer & 0.15 & & $1.04(1.00-1.09)$ \\
Anglo & & 0.04 & - \\
Contact with cats & 0.04 & & 10 \\
Yes & - & & \\
No & & & \\
\hline
\end{tabular}

*PR: prevalence ratio. 


\section{DISCUSSION}

The prevalence of approximately 33\% for T. gondii in goats in Santa Catarina, was lower than in Paraná state (44.68\%) [31], and higher than reported in Rio Grande do Sul state (30\%) [22], the two Brazilian states that make territorial boundary with Santa Catarina state. Statistically and numerically higher prevalence was found in the western region of the state. According to literature, the prevalence of toxoplasmosis varies from region to region, been influenced by the climate, geographical factors, human and animals habits [16]. Another study has also already reported difference between regions in the State of Bahia [17], where the number of positive animals was higher in the region of with higher temperatures and humid climate, similar to what occurred in this study, that because this climate favors sporulation, and thus enables the oocysts to become contaminants to the animals $[21,23]$.

In this study, similar to other epidemiological studies with goats and $T$. gondii [31,32], in a univariate analysis, gender of the animal was identified as risk factor for $T$. gondii, occurring in greater numbers in females. According to the literature, some factors may contribute to this situation, as the females stay longer on the farm (with greater chance of exposure to the parasite) and/or immunosuppression during pregnancy and lactation [34]. A higher prevalence of $T$. gondii infection in adult animals was found, similar to that reported by other researchers [26], who observed a positive association between older animals and the presence of antibodies, and thus greater chance of exposure to the etiological agent $[5,13,19]$. In this study, unlike the univariate analysis, the multifactorial model, did not kept the variables sex and age as risk factors for $T$. gondii infection in goats.

The goat's breed was considered statistically a risk factor for disease in the current study; the animals belonging to Boer breed were mainly affected, although $70 \%$ of the goats were without race defined animals. Otherwise, others demonstrated a higher $(32.7 \%)$ susceptibility wend animals were Mongrel [1], compared to goats purebred (18.6\%). Despite some justification for breed been a risk factor, the authors consider difficult to find an explanation for breed to be a risk factor for toxoplasmosis since the infection is related to exposure to the etiological agent by the oral route (oocyst ingestion) or vertical, it has never been published any description about breed resistant or susceptibility of infection by the parasite.

The type of food and water source given to the animals was not considered a risk factor for $T$. gondii infection, although some authors mention that cat feces contaminated with oocysts of the parasite can be more easily ingested in the diet with concentrated (cats have access) and natural water sources [14,28]. According to literature [15], the most common form of infection among goats is by ingestion of oocysts agent that are present in soil, food and water contaminated by cat feces (definitive host). This study showed that $53 \%$ of the animals studied had contact with cats, and this variable was considered a risk factor for disease, ie, most of the goats that had seropositive results had contact with cats. A similar result was reported by other researcher [2], where the labeling index was higher in farms where goats contact with cats.

Infection by $T$. gondii in sheep is usually associated with reproductive problems [35]. However in our study, statistically, unverified relationship between reproductive problems and goats seropositive for $T$. gondii, although of approximately $24 \%$ of the animals studied showed some reproductive problems (abortion, mummified or heat repetition). Similarly, researcher also report that reproductive failure, alone, were not associated with seropositivity to $T$. gondii [6], unlike cases of coinfection ( $T$. gondii and virus infectious arthritis goat). Other study also observed no relationship between seropositive goats and reproductive failure [32]. Therefore, other infectious diseases may be related to reproductive problems reported in goats.

In the effect-cause analysis, neurological issues were related to infection by $T$. gondii in goats. This can easily be explained because the parasitic cysts of $T$. gondii may persist in the central nervous system (CNS) for a long period [11]. Consequently, the parasite in the brain can cause severe inflammatory infiltrates and histological lesions, and hence to enable the occurrence of encephalitis, described in goats with toxoplasmosis [8]. The relationship with toxoplasmosis and neurological disorders in humans [20], dogs [30] and experimentally infected rodents [18] are well described.

Our serological results were quite similar to those obtained from other studies throughout the Brazil, showing relatively low positivity for $T$. gondii. 
However, our results show some risk factors to $T$. gondii infection in goats such as region, breed, and contact with cats, as well as neurologic problems is a cause of disease. Thus, it is possible to conclude that toxoplasmosis is present in approximately one third of goats of the western and mountain regions of the state of Santa Catarina, Brazil, and is associated with some important risk factors.
MANUFACTURER

${ }^{1}$ Sigma-Aldrich. São Paulo, SP, Brazil.

Ethical approval. The procedure was approved by the Animal Welfare Committee of Universidade do Estado de Santa Catarina, number 1.02.12.

Declaration of interest. The authors report no conflicts of interest. The authors alone are responsible for the content and writing of the paper.

\section{REFERENCES}

1 Alvarado-Esquivel C., Garcia-Machado C., Vitela-Corrales J., Villena I. \& Dubey J.P. 2012. Seroprevalence of Toxoplasma gondii infection in domestic goats in Durango State, Mexico. Veterinary Parasitology. 183(1-2): 43-46.

2 Araújo F.R., Sarti E.C., Balbuena C.B., Carvalho C.M.E. \& Ramos J.K. 1998. Levantamento sorológico para Toxoplasma gondii em caprinos na microrregião de Campo Grande, Mato Grosso do Sul. Revista Ensaios e Ciência. 2(2): 141-148.

3 Barros A.J.D. \& Hirakata V. 2003. Alternatives for regression in cross-seccional studies: an empirical comparision of models that directly estimate the prevalence ratio. BMC Medical Research Methodology. 3(1): 21-22.

4 Camargo M.E. 1964. Improvided technique of indirect immunofluorescence for serological diagnosis of toxoplasmosis. Revista do Instituto de Medicina Tropical. 6(3): 117-118.

5 Carneiro A.C.A.V. 2006. Soro-epidemiologia da toxoplasmose caprina e ovina no estado de Minas Gerais. 134f. Belo Horizonte, MG. Dissertação (Mestrado em Parasitologia) - Instituto de Ciências Biológicas, Universidade Federal de Minas Gerais.

6 Costa H.F., Stachissini A.V.M., Langoni H., Pandovani C.R., Gennari S.M. \& Modolo J.R. 2012. Reproductive failures associated with antibodies against caprine arthritis-encephalitis virus, Toxoplasma gondii and Neospora caninum in goats in the state of Sao Paulo, Brazil. Brazilian Journal of Veterinary Research and Animal Science. 49(1): 67-72.

7 Deddens J.A. \& Petersen M.R. 2008. Approaches for estimating prevalence ratios. Occupational and Environmental Medicine. 65(7): 501-506.

8 Dubey J.P. 1987. Toxoplasmosis in goats. Agriculture Practice. 8(1): 43-52.

9 Dubey J.P. 1988. Lesions in transplacentally induced toxoplasmosis in goats. American Journal of Veterinary Research. 49(6): 905-909.

10 Dubey J.P. \& Beattie C.P. 1988. Toxoplasmosis of animals and man. 2nd edn. Boca Raton: CRC Press Inc, 220p.

11 Dubey J.P., Lindsay D.S. \& Speer C.A. 1998. Structures of Toxoplasma gondii tachyzoites, bradyzoites and sporozoites and biology and desenvolviment of tissue cysts. Clinical Microbiology Reviews. 11(2): 267-299.

12 Engeland I.V., Waldeland H., Kindahl H., Ropstad E. \& Andressen O. 1996. Effect of Toxoplasma gondii infection on the development of pregnancy and on endocrine foetal-placental function in the goat. Veterinary Parasitology. 67(1-2): 61-74.

13 Figliuolo L.P.C., Rodrigues A.A.R., Viana R.B., Aguiar D.M., Kasai N. \& Gennari S.M. 2004. Prevalence of anti-Toxoplasma gondii and anti-Neospora caninum antibodies in goats from São Paulo State, Brazil. Small Ruminant Research. 55(1): 29-32.

14 Frenkel J.K., Hassanein K.M., Hassanein R.S., Brown E., Thulliez P. \& Quiteronunez R. 1995. Transmission of Toxoplasma gondii in Panama-City. The American Journal of Tropical Medicine and Hygiene. 53(5): 458-468.

15 Garcia, G. 2010. Soroepidemiologia da toxoplasmose caprina na mesorregião metropolitana de Curitiba, Paraná - Brasil. 123f. Dissertação (Mestrado em Ciências Biológicas) - Curso de Pós-graduação em Microbiologia, Parasitologia e Patologia. Universidade Federal do Paraná.

16 Garcia J.L., Navarro I.T., Ogawa L. \& Oliveira R.C. 1999. Soroprevalência do Toxoplasma gondii em suínos, bovinos, ovinos e equinos, e sua correlação com humanos, felinos e caninos, oriundos de propriedades rurais do norte do Paraná, Brasil. Ciência Rural. 29(1): 91-97.

17 Gondim L.F.P., Barbosa H.V., Ribeiro Filho C.H.A. \& Saeki H. 1999. Serological survey of antibodies to Toxoplasma gondii in goat, sheep, cattle and water buffaloes in Bahia State, Brazil. Veterinary Parasitology. 82(3): 273-276. 
18 Gatkowska J., Dziadek B., Dzitko K., Dlugonska H. \& Wieczorek M. 2012. Behavioral changes in mice caused by Toxoplasma gondii invasion of brain. Parasitology Research. 111(1): 53-58.

19 Jittapalapong S., Sangvaranond A., Pinyopanuwat N., Chimnoi W., Khachaerm W., Koizumi S. \& Maruyama S. 2005. Seroprevalence of Toxoplasma gondii infection in domestic goats in Satun Province, Thailand. Veterinary Parasitology. 127(1): 17-22.

20 Kamerkar S. \& Davis P.H. 2012. Toxoplasma on the brain: understanding host-pathogen interactions in chronic CNS infection. Journal of Parasitology Research. 2012: 589295.

21 Lynfield R., Hsu H.W. \& Guerina N.G. 1999. Screening methods for congenital toxoplasmosis and risk of disease. Lancet. 353(9168): 1899-1900.

22 Maciel K.P. \& Araujo F.A.P. 2004. Inquérito sorológico para detecção de anticorpos de Toxoplasma gondii em caprinos (Capra hircus) criados nos municípios de Gravataí e Viamão, região da Grande Porto Alegre, Rio Grande do Sul, Brasil. Revista de Ciências Agroveterinárias. 3(2): 121-125.

23 McAuley J., Boyer K. M., Patel D., Mets M., Suvsher C. \& Roizen N. 1994. Early and longitudinal evaluations of treated infants and children and untreated historical patients with congenital toxoplasmosis: the Chicago collaborative treatment trial. Clinical Infectious Diseases. 18(1): 38-72.

24 Medronho R.A., Bloch K.V., Raggio R. \& Werneck G.L. 2009. Epidemiologia. 2.ed. São Paulo: Atheneu, 685p

25 Mehdi N.A., Kazacos K.R. \& Carlton W.W. 1983. Fatal disseminated toxoplasmosis in goats. Journal of American Veterinary Medical Association. 183(1): 115-117.

26 Modolo J.R., Lagoni H., Padovani C.R., Barrozo L.V., Leite B.L.S., Gennari S.M. \& Stachissini A.V.M. 2008. Avaliação da ocorrência de anticorpos anti-Toxoplasma gondii, em soros de caprinos do estado de São Paulo, e associação com variáveis epidemiológicas, problemas reprodutivos e risco à saúde pública. Pesquisa Veterinária Brasileira. 28(12): 606-610.

27 Munday B.L. \& Manson R.W. 1979. Toxoplasmosis as a cause of perinatal death in goats. Australian Veterinary Journal. 55(10): 485-487.

28 Navarro I.T., Vidotto O., Giraldi N. \& Freire R.L. 1992. Toxoplasma gondii, isolamento em carnes e cérebro de suínos. Semina: Ciências Agrárias. 13(1): 10-15.

29 Neto J.O.A., Azevedo S.S., Gennari S. M., Funada M.R., Pena H.F.J., Araujo A.R.C.P., Batista C.S.A., Silva M.L.C.R., Gomes A.A.B., Piatti R.M. \& Alves C.J. 2008. Prevalence and risk factors for anti-Toxoplasma gondii antibodies in goats of the Seridó Oriental microregion, Rio Grande do Norte state, Northeast region of Brazil. Veterinary Parasitology. 156(3-4): 329-332.

30 Plugge N.F., Ferreira F.M., Ricgartz R.R.T.B., Siqueira A. \& Dittrich R.L. 2011. Occurrence of antibodies against Neospora caninum and/or Toxoplasma gondii in dogs with neurological signs. Revista Brasileira de Parasitologia Veterinária. 20(3): 202-206.

31 Reis C.R., Lopes F.M.R., Gonçalves D.D., Freire R.L., Garcia J.L. \& Navarro I.T. 2007. Occurrence of antiToxoplasma gondii antibodies in caprines from Pitanga City, Paraná State, Brazil. Brazilian Journal of Veterinary Research and Animal Science. 44(5): 358-363.

32 Silva A.V., Cunha E.L.P., Meireles L.R., Gottschalk S., Mota R.A. \& Langoni H. 2003. Toxoplasmose em ovinos e caprinos em duas regiões do estado de Pernambuco, Brasil. Ciência Rural. 33(1): 115-119.

33 Tenter A.M., Heckeroth A.R. \& Weiss L.M. 2000. Toxoplasma gondii: from animals to humans. International Journal for Parasitology. 30(12-13): 1217-1258.

34 Uzêda R.S., Fernández S.Y., Jesus E.E.V., Pinheiro A.M., Ayres M.C.C., Spinola S., Barbosa Junior H.V. \& Almeida M.A.O. 2004. Fatores relacionados à presença de anticorpos IgG anti-Toxoplasma gondii em caprinos leiteiros do Estado da Bahia. Revista Brasileira de Saúde e Produção Animal. 5(1): 1-8.

35 Weissmann J. 2003. Presumptive Toxoplasma gondii abortion in a sheep. Canadian Veterinary Journal. 44(4): 322324. 